\title{
Earnings quality, earnings management and religiosity: A literature review
}

\author{
Konrad Grabiński, Piotr Wójtowicz
}

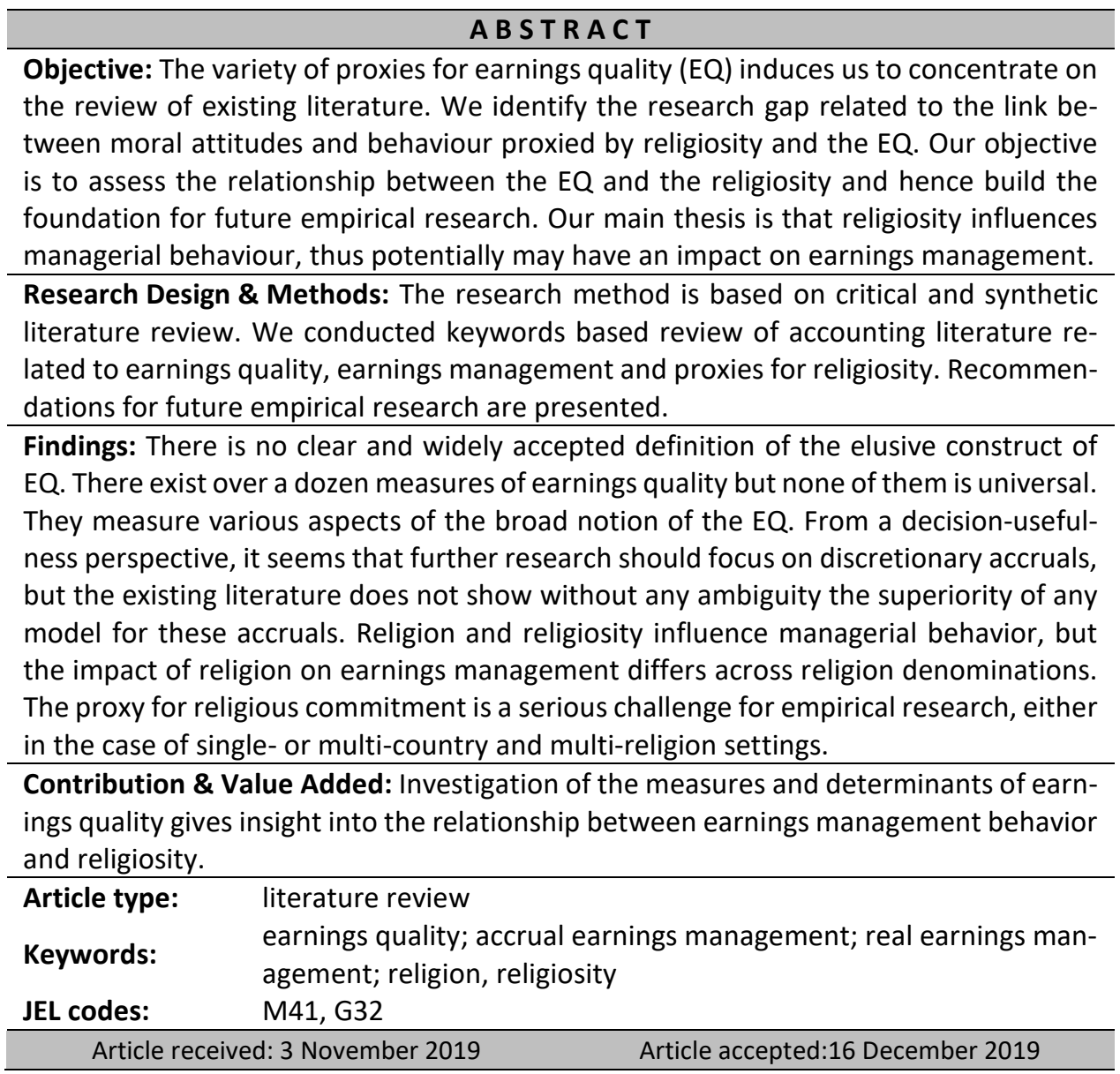

\section{Suggested citation:}

Grabiński, K., \& Wójtowicz, P. (2019). Earnings quality, earnings management and religiosity: A literature review. International Entrepreneurship Review (previously published as International Entrepreneurship I Przedsiębiorczość Międzynarodowa), 5(4), 41-57. https://doi.org/10.15678/IER.2019.0504.03 


\section{INTRODUCTION}

The notion of earnings quality (EQ) builds on the assumption that financial statements are useful to investors and other capital providers in making their resource allocation decisions. It is perceived as a key characteristic of financial reporting. However, EQ is an elusive construct and researchers, as well as practitioners, understand it in many different ways. We are not aware of any generally accepted definition and measure of $E Q$, but in this paper we review a variety of proxies for it, focusing on particular attributes of earnings.

The variety of proxies for EQ induces us to concentrate on the review of existing literature in this area. We identify the research gap related to the link between moral attitudes and behavior proxied by religiosity and the EQ. The notion of religiosity, however apparently clear, touches various aspects of different religions and is elusive too. Researchers usually do not have at their disposal the data related to personal religiosity of managers responsible for financial reporting. Thus, our objective is to build the foundation for future empirical research on the relationship between the EQ and the religiosity. Our main thesis is that religiosity influences managerial behavior, thus potentially may have an impact on EM.

The paper is organized as follows. In the first section, the notion of the earnings quality (EQ) is described on the basis of many definitions provided in accounting literature. Then most commonly used measures of the EQ are presented, which is followed by the section describing the most important determinants driving EQ. The next section focuses on earnings management (EM) as a subset of the EQ problem. In more detail, the definition of EM is analyzed and the role of the manager as an EM decision-maker. The last section is devoted to the link between religion, religiosity and earnings management.

\section{MATERIAL AND METHODS}

The paper uses a critical analysis as the main research method. We selected papers using the terms "earnings quality", "earnings management" and "religiosity" in the EBSCOhost database. From the enormous number of earnings management related items (over 8,000 ) we selected mainly articles published in high-rated journals, linking the notion of earnings management and religiosity. We also refer to monographs and publicly available data presented by FTSE Russell, Gallup and Pew Research Center.

\section{LITERATURE REVIEW}

\section{Earnings quality: The problem of definition}

Earnings quality is perceived as a key characteristic of financial reporting. However, EQ is an elusive construct and researchers, as well as practitioners, understand it in many different ways. Nelson and Skinner (2013) concluded, that there is a lack of consensus with regard to the definition and measurement of EQ. Thereby there are at least over a dozen measures of EQ, which are present in accounting literature. So far, we are not aware of any generally accepted definition and measure of EQ, but in this paper we review a variety of proxies for it, focusing on particular attributes of earnings. It seems that there is no consensus on the definition of EQ, or even on what this construct is intended to. Simultaneously, there exists a huge amount of academic research assessing it. 
The first mention of the EQ could be traced back to the year 1934 when the book "Security Analysis" by Graham and Dodd (1934) was published. The value of the company was defined as a product of multiplication of the $P / E$ ratio and the so-called "quality ratio". The latter one was a proxy for the "strength of the earnings", which incorporates a wide variety of information like dividend policy, company size, reputation, financial situation, future perspectives, etc. In fact, that was the late 60-es of the XX century, when the pioneer empirical research on EQ started (Grabiński, 2016). Two very prominent papers were published in the year 1968, which started empirical research in accounting and at the same time laid the foundations for the theory of EQ. The first paper presents the study of Ball and Brown (1968), who assumed that the useful information should influence investor's behavior. Therefore, the moment the financial statement is published and financial information became publicly available should translate into a change in a share price in a short time-window. The second paper presents the study of Beaver (1968), who noticed that influential accounting information (earnings) should translate into investors' behavior, and therefore should motivate them to make investment decisions, resultant in a higher volume of transactions. Accounting theorists, as it was pointed out by Lev (1989), define EQ as informational content of earnings, which is defined as a strong correlation between accounting earnings and the rate of return on shares of the company listed on the stock exchange.

Dechow, Ge and Schrand (2010) define the high quality of earnings as providing more information about the features of a firm's financial performance that are relevant to a specific decision made by a specific decision-maker. Therefore, the concept of the EQ cannot be analyzed without the context of the decision-maker. Essentially the EQ is determined by two main factors: innate underlying economic performance and the system of financial reporting within the reporting entity. The main goal of financial reporting is to measure the innate economic performance and the crucial question is how reliable is the financial statement in terms of depicting the underlying economic situation. As Dechow et al. (2010) point out, the main task of empirical research is to separate the "innate" factor and the "reporting" factor. The basic assumption is that the "innate factor" changes very slowly in time and is sector-specific when the "reporting factor" is much more volatile and discretionary, dependant on the management decision.

Schipper and Vincent (2003) relate EQ both to decision usefulness, and to the economicsbased definition of income developed by Hicks (1946). Unfortunately, the perspective of decision usefulness is context-specific because there are many users and uses of financial statements. As a result, the usefulness of accounting numbers must be evaluated in the context of some assumptions, and the conclusions are conditional on the context, in other words, they may not be universal. On the contrary, the Hicksian concept of income is context-neutral, but from an accounting perspective it refers to the non-operational idea of representational faithfulness. Schipper and Vincent (2003,) define EQ as "the extent to which reported earnings faithfully represent Hicksian income, where representational faithfulness means correspondence or agreement between a measure of description and the phenomenon that it purports to represent"(p.98). The practical problem is that accounting earnings do not measure Hicksian income, no matter if we use IFRS, US GAAP or other accounting systems.

Francis, Olsson and Schipper (2006) also point out that EQ, as a construct, implies nothing about its measurement because it is context-specific. They do not define EQ but 
they follow the above concept of decision usefulness and they associate earnings quality with precision, i.e. the higher the $E Q$, the more precise is earnings with respect to an underlying valuation-relevant construct that it is intended to describe. They discuss the concept of EQ in the broad perspective of information quality, then focus on financial reporting quality and finally consider EQ as an indicator of financial reporting quality. Instead of defining clearly EQ they provide discussions of several EQ measures and determinants.

The IASB and the FASB agendas highlight that the EQ is the utmost and the most important goal of policymakers. It is due to the widely accepted assumption that high-quality earnings help investors to make better investors decisions and thereby improve the capital allocation process from a macroeconomic perspective. Going in this line of reasoning we can refer to Dechow et al. (2010) definition of the EQ, which states that high-quality earnings should depict current economic efficiency and at the same time should be a good proxy for the future performance. Therefore, it should be a useful input in the process of the shareholder value's estimation. They mention that high-quality earnings should also be predictable and persistent, and all the above are not the complete picture of the EQ concept, which consists also of many other elements.

We may draw a provisional and rather perplexing conclusion at this point. There is no clear and widely accepted definition of EQ. Nevertheless, there exist many research papers assessing its various operationalized aspects. Building on Statement of Financial Accounting Concepts No. 8 (FASB, 2010) we follow the idea of faithful representation and we propound that earnings are of high quality if they faithfully represent the phenomena that they purport to represent. This conclusion induces us to deeply investigate the determinants and measures of the elusive construct of $E Q$.

\section{Measures of earnings quality}

Francis, LaFond, Olsson and Schipper (2004) list seven proxies for EQ, while Perotti and Wagenhofer (2014) used eight among the existing in the literature (only five proxies are used in both papers). They divide these proxies into two groups: accounting-based and market-based. Accounting-based measures only use accounting earnings and their components. Market-based measures use accounting earnings and market returns. Within the group of accounting-based EQ measures, they identified three subcomponents: measures based on the time series of earnings, on their volatility or smoothness, and on the unexpected part of accounting accruals.

The two measures based on a time-series are persistence and predictability. Persistence is equal to the slope coefficient $\alpha_{1}$ of the following regression:

$$
N I_{i, t}=\alpha_{0}+\alpha_{1} N I_{i, t-1}+\varepsilon_{i, t}
$$

where $N I$ (net income reported) is scaled by total assets at the beginning of period $t$. Predictability is the $R^{2}$ of this regression.

Perotti and Wagenhofer (2014) use two smoothness measures based on the volatility of earnings or accruals relative to the volatility of operating cash flows. They note that these measures assume that operating cash flows are not subject to earnings management. This is obviously not true. Cash from operating activities is not sensitive to accrual earnings management, but it is influenced by real activities, and hence it is subject to managers' discretion. They use the standard deviation of earnings divided by the standard deviation of cash flow from operations CFO, both NIBE and CFO scaled by beginning total assets: 


$$
s\left(N_{B B E_{i, t}}\right) / s\left(\mathrm{CFO}_{i, t}\right)
$$

and the correlation of accruals $\mathrm{ACC}$ and cash flow from operations:

$$
\mathrm{r}\left(\mathrm{ACC}_{i, t}, \mathrm{CFO}_{i, t}\right)
$$

One view is that smoothness is negatively associated with EQ because it is the final outcome of intentional actions taken by managers, i.e. an attempt to blur the firm's performance, and hence reduces the information value of reported earnings (Nanda, Leuz, \& Wysocki, 2003). An alternative, more comprehensive view, builds on the observation that accounting earnings are the sum of operating cash flows and accounting accruals. The users of financial statements use earnings in their decision-making process, although they can ignore earnings and use cash flows only. In such a case some smoothness must be desirable because it reduces volatility of cash flows. Furthermore, due to reversing nature of accounting accruals, smoothing incorporates managers' private information and experience. Under this view, smoothness is positively associated with EQ.

The next set of EQ measures concentrates on accounting accruals. One, extremely popular approach, follows the paper of Jones (1991). Abnormal accruals are the residuals from the following model:

$$
A C C_{i, t}=\alpha_{0}+\alpha_{1} \Delta R E V_{i, t}+\alpha_{2} P P E_{i, t}+\varepsilon_{i, t}
$$

Dechow, Sloan and Sweeney (1995) proposed modified version of Jones model:

$$
A C C_{i, t}=\alpha_{0}+\alpha_{1}\left(\Delta R E V_{i, t}-\triangle A R_{i, t}\right)+\alpha_{2} P P E_{i, t}+\varepsilon_{i, t}
$$

where $\triangle \mathrm{REV}$ is the change in revenues, $\triangle \mathrm{AR}$ is the change in accounts receivable, and PPE is gross property, plant, and equipment (all variables scaled by beginning total assets). The abnormal accruals measure is the residuals from (5). Stubben (2010) finds that the original Jones model exhibits better specification than the modified Jones.

All Jones-like models assume that it is possible to split accruals into "normal" and "abnormal" part. The former is the result of "normal" operating activity of the firm, the latter is the outcome of managers' discretion, constrained by reversing nature of accruals, private information, and also influence of the environmental conditioning (e.g. other executive officers, mid-level managers or local community) and personal characteristics (e.g. education, attitude towards risk, religiosity). The high absolute value of abnormal accruals is interpreted as an indicator of low EQ because abnormal accruals are likely to be discretionary. The alternative approach, less popular, is that abnormal accruals are the accounting-based means of communicating managers' private information (Perotti \& Wagenhofer 2014). In such a case abnormal accruals are an indicator of high EQ, reduced by intentional earnings management.

The mentioned above models for abnormal accruals estimation assume implicitly that managerial intervention in the reporting process occurs via accounting estimates and methods, so they refer to so-called accrual earnings management (AEM). Roychowdhury (2006) notes that managers may also manage earnings through operational decisions, like the acceleration of sales or alterations in shipment schedules. He defines real activities manipulation as 'departures from normal operational practices, motivated by managers' desire to mislead at least some stakeholders into believing certain financial reporting goals have been met in the normal course of operations"(p.337). His definition and analysis refer to so-called real earnings management (REM). These departures enable managers to meet reporting goals but do not necessarily increase the value of a firm. 
To study the level of REM Roychowdhury (2006) uses three measures derived from the model developed by Dechow, Kothari and Watts (1998). Acceleration of the timing of sales through increased price discounts or more convenient credit terms is proxied by the difference between normal and actual CFO. Normal CFO is expressed as a linear function of sales and change in sales:

$$
\frac{C F O_{i, t}}{A_{i, t-1}}=\alpha_{0}+\alpha_{1}\left(\frac{1}{A_{i, t-1}}\right)+\alpha_{2}\left(\frac{S_{i, t}}{A_{i, t-1}}\right)+\alpha_{3}\left(\frac{\Delta S_{i, t}}{A_{i, t-1}}\right)+\varepsilon_{i, t}
$$

Reporting of the lower cost of goods sold through increased production is proxied by the difference between normal and actual production costs $P R O D$. The following model is used to estimate the normal level of production costs (Roychowdhury 2006):

$$
\frac{P R O D_{i, t}}{A_{i, t-1}}=\alpha_{0}+\alpha_{1}\left(\frac{1}{A_{i, t-1}}\right)+\alpha_{2}\left(\frac{S_{i, t}}{A_{i, t-1}}\right)+\alpha_{3}\left(\frac{\Delta S_{i, t}}{A_{i, t-1}}\right)+\alpha_{4}\left(\frac{\Delta S_{i, t-1}}{A_{i, t-1}}\right)+\varepsilon_{i, t}
$$

Finally, to assess the level of REM resultant form decreases in discretionary expenses DISEXP, including advertising, R\&D, and SG\&A expenses Roychowdhury (2006) estimates the normal level of DISEXP:

$$
\frac{\operatorname{DISEXP}_{i, t}}{A_{i, t-1}}=\alpha_{0}+\alpha_{1}\left(\frac{1}{A_{i, t-1}}\right)+\alpha_{2}\left(\frac{s_{i, t-1}}{A_{i, t-1}}\right)+\varepsilon_{i, t}
$$

Roychowdhury's (2006) approach has two limitations. Firstly, only abnormal CFO is a comprehensive and universal variable available for every firm and industry, e.g. Roychowdhury analyzes contrived production costs for non-production firms. Secondly, revenues from early in the year are treated in the same way as revenues from later in the year. Stubben (2010) overcomes the latter limitation. His findings indicate that measures of discretionary revenues produce estimates with substantially less bias and measurement error than those of accrual models, discretionary revenues can detect not only revenue management but also earnings management via revenues. Finally, he finds that the revenue model is less likely than accrual models to falsely indicate EM, and more likely than accrual models to detect EM management when it does occur.

Following Stubben (2010) we suggest the modification of Roychowdhury's (2006) approach. We express normal CFO as a linear function of sales and change in sales in the current period, but we split current year sales into the first three quarters sales S1-3, and sales in the fourth quarter $S 4$ :

$$
\frac{C F O_{i, t}}{A_{i, t-1}}=\alpha_{0}+\alpha_{1}\left(\frac{1}{A_{i, t-1}}\right)+\beta_{1}\left(\frac{s 1-3_{t}}{A_{i, t-1}}\right)+\beta_{2}\left(\frac{S 4_{t}}{A_{i, t-1}}\right)+\beta_{3}\left(\frac{\Delta S_{t}}{A_{i, t-1}}\right)+\varepsilon_{i, t}
$$

Early sales usually are collected in cash before the end of the fiscal year. We hypothesize that the level of REM increases in the 4th quarter, and hence sales made late in the year are more likely to remain on account at year-end. The ability of the modified accrual models to detect REM needs to be investigated.

A second accruals-based measure is accruals quality (Dechow \& Dichev, 2002). They derive an empirical measure of accrual quality as the residuals from firm-specific regressions of changes in working capital $\triangle W C$ on past, present, and future operating cash flows:

$$
\Delta W C_{i, t}=\alpha_{0}+\alpha_{1} C F O_{i, t-1}+\alpha_{2} C F O_{i, t}+\alpha_{3} C F O_{i, t+1}+\varepsilon_{i, t}
$$

The residuals from the above regression reflect the accruals that are unrelated to cash flow realizations, and the standard deviation of these residuals is a firm-level measure of 
accrual quality, where higher standard deviation denotes lower quality. Despite its popularity, it is difficult to be used because the future CFO is not known at the time of estimation. According to prior literature, the better the mapping explains the accruals, the lower is the residual from a regression based on these cash flows and the higher is the EQ. Some empirical literature suggests that accruals quality is superior to other accounting-based measures, and therefore it is used in many studies (Eliwa, Gregoriou, \& Paterson, 2019). On the other hand, accruals quality is subject to concerns similar to those noted for abnormal accruals. The residuals reflects earnings management and potentially useful information. Nevertheless, Stubben (2010) concludes that the Dechow-Dichev model exhibits greater misspecification than other accrual models when used to estimate discretionary accruals.

Francis et al. (2004) list timeliness and conservatism among the accounting-based measures of EQ. They derive their reasoning from the view that accounting earnings are intended to measure economic income, defined as changes in the market value of equity. The timeliness is the explanatory power of a reverse regression of earnings on returns and conservatism is the ratio of the slope coefficients on negative returns to the slope coefficients on positive returns in a reverse regression of earnings on returns. Conservatism, therefore, differs from timeliness in that it reflects the differential ability of accounting earnings to reflect economic losses (measured as negative stock returns) versus economic gains (measured as positive stock returns). Combined timeliness and conservatism are sometimes described as "transparency".

Value relevance is the most common market-related measure of the EQ and is measured by the slope coefficient in a regression of the market returns on earnings, so-called earnings response coefficient (Perotti \& Wagenhofer, 2014):

$$
R_{i, t}=\alpha_{0}+\alpha_{1} N I_{i, t}+\varepsilon_{i, t}
$$

where $R i, t$ is the 12-month return ending 3 either 4 months after the end of the fiscal year $t$ (e.g. Daly, 2018; Karamanou, 2012). NI is scaled by the market value of equity at the beginning of period $t$. High-value relevance is generally considered to indicate high earnings quality. The last commonly used market-based EQ measure is $R^{2}$ of the above regression. Ewert and Wagenhofer (2012) find value relevance being most closely related to EQ. Jakubowski and Wójtowicz (2019) find that the value relevance of accounting earnings in Poland is very low, relative to the value relevance of earnings forecasts.

\section{Determinants of earnings quality}

We have outlined the plethora of EQ measures and we may conclude that despite the lack of precise definition and commonly accepted proxy (ten proxies defined), EQ exists and may depend on many factors, including economic and environmental conditions (for instance legal enforcement or level of corruption), business model of a firm, financial reporting system (including audit quality), activities of intermediaries (for instance analysts and financial press), goals and incentives of managers in making their reporting choices (including moral attitudes). However, the existing literature broadly discussing determinants of EQ is very scant (Dechow et al., 2010; Francis et al., 2006).

Francis et al. (2004) distinguish innate (operating and environmental) and discretionary (reporting) determinants of EQ. Innate determinants derive from business models and operating environments. Discretionary determinants are associated with accounting choices, implementation decisions, managerial error, auditing, governance, and enforcement. Francis 
et al. (2006) claim that innate factors are changing slowly relative to factors that influence discretionary EQ, nevertheless, some changes can be abrupt (exiting a line of business) while others can be gradual (building a brand). The final outcome of the possible empirical research depends on the ability to identify and separate innate and discretionary factors.

Reporting sources of EQ arise from the financial reporting process, including (Francis et al. 2006):

- management's financial reporting implementation decisions, including judgments and estimates,

- the quality of the information systems used to support financial reporting,

- monitoring activities, including internal and external audits,

- governance activities, boards of directors, compensation arrangements, and ownership structures,

- regulatory scrutiny, including the extent and nature of securities laws and the enforcement of those laws,

- reporting standards.

We will concentrate on management decisions because we conjecture that despite the extensive research on earnings management (EM) there are still avenues for future research. A large body of accounting literature analyzes financial reporting decisions examining both incentives for earnings management and its consequences. Financial reporting and reported earnings are one of the key outputs of the managerial decision-making process. Managerial discretion is very present in financial reporting practice and allowed by accounting regulations, which is considered to be the main opportunity for earnings management behavior. In consequence, it can be expected that EM behavior - according to upper echelon theory (Hambrick \& Mason 1984) - should be explained at least partially by CEO's interpretation of encountered situations, and this, in turn, should be depended on the CEO's environmental and personal characteristics (i.e. values, educational background, etc.). The researcher should address two areas affecting the CEO's interpretation and behavior having supposedly impact on the EM: environmental conditioning and personal/psychological traits. There are of course many proxies for environmental conditioning, but the religiosity of the local community seems to be especially interesting. CEO's psychological features must be proxied by a set of control variables, which influence EM behavior and have been already documented in other studies.

\section{Definition of earnings management}

Ronen and Yaari (2008) discuss the definition of earnings management and classify them into three categories: white, gray and black. White (or beneficial) EM enhances the transparency of financial reporting (e.g. Beneish, 2001). Grabiński, Kędzior and Krasodomska (2014) state that the complete lack of EM practice is considered negatively by the stock market. Gray EM is the manipulation of reports within the boundaries of compliance with standards. It can be either opportunistic or efficiency-enhancing (Arya, Glover, \& Sunder, 2003). Finally, black (or pernicious) involves misrepresentation, fraud and reduced transparency of the financial reports (e.g. Schipper, 1989).

Ronen and Yaari (2008) try to summarize the three strands of thought on EM by quoting Healy and Wahlen (1999) who define the EM in the following way: "earnings management occurs when managers use judgment in financial reporting and in structuring transactions to 
alter financial reports to either mislead some stakeholders about the underlying economic performance of the company or to influence contractual outcomes that depend on reported accounting numbers" (p. 26). However, they note that not all EM is misleading. For example, managing earnings, in order to allow separation of persistent earnings from the effects of a one-time transaction, help investors evaluate future prospects of the firm. Therefore, they offer alternative definitions of EM: "earnings management is a collection of managerial decisions that result in not reporting the true short-term, value-maximizing earnings as known to management. Earnings management can be beneficial: it signals long-term value; pernicious: it conceals short- or long-term value; neutral: it reveals the short-term true performance. The managed earnings result from taking production/investment actions before earnings are realized, or making accounting choices that affect the earnings numbers and their interpretation after the true earnings are realized" (p.27).

The last sentence in the above definition distinguishes between real earnings management (actions before earnings are realized) and accrual earnings management (accounting choices that affect the earnings numbers). Both definitions emphasize the role of managerial decisions/judgment in EM practice. In other words, the prevalence and extent of earnings management result from incentives, quality of reporting and auditing system or legal enforcement, and from managers' social and personal conditioning too.

\section{Manager as earnings management decision-maker}

The classical school of economy defines a decision-maker as a "unique actor whose behavior is not only intelligent but rational. The decision is the choice this actor makes, in full awareness, from among all the possible alternatives he has, in order to maximize his advantages..." and chooses the alternative that procures maximum gain or satisfaction (Gremion, Boyko, \& Boddewyn, 1972, p. 126). The refinement of decision-making theory states that the criteria of satisfaction depend on the personal values of the actor and perception/interpretation of reality. So the concept of "homo economicus", who was assumed to be a rational actor evolved to the concept of the decision-maker, whose rationality is subjective and relative.

Building on this notion Hambrick and Mason (1984) proposed an upper echelon theory stating that organizational outcomes - strategic choices and performance levels - are partially explained by managerial background characteristics like age, career experiences, education, socioeconomic roots, group characteristics. Hambrick (2007) twenty years later proposed an enhancement of the theory definition stating that the CEO's experiences, values, and personalities greatly influence interpretations of the encountered situations and in turn affect their choices and courses of action. One of the key development of the theory is introducing a moderator - managerial discretion (Hambrick \& Finkelstein, 1987), which is defined later by Hambrick (2007) as "an absence of constraint and when there is a great deal of means-ends ambiguity - that is, when there are multiple plausible alternatives"(p.335). Hambrick (2007) explains that this theory is especially valid in situations where managerial discretions exist.

The other set of factors influencing managers' decisions is explained by Kohlberg (1984). He claims that most adults judge the morality of actions by comparing them to society's views and expectations. The conventional morality is characterized by an acceptance of society's conventions concerning right and wrong, and a rule's appropriate- 
ness or fairness is seldom questioned. Individuals will behave and act in a way that conforms to the behavioral norms of the groups and the local society he/she belongs to. Local religious norms represent the type of social influence that is likely to affect the attitudes of managers of firms headquartered in a given area.

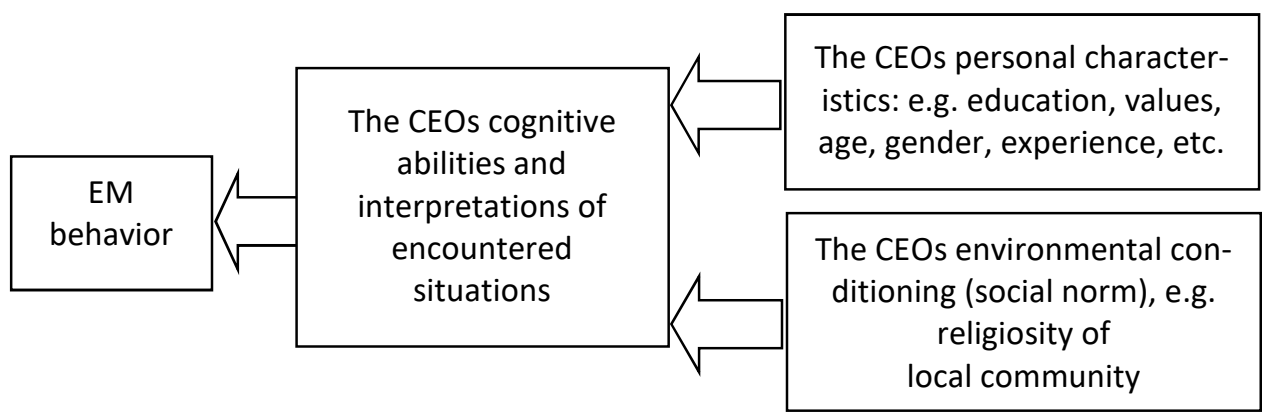

Figure 1. The relationship between EM behaviour, personal characteristics and environmental conditioning of CEOs

Source: own elaboration.

For instance, Conroy and Emerson (2004) use church attendance as a proxy for religiosity. They show that it is associated with lower acceptance of the use of accounting manipulation. Longenecker, McKinney and Moore (2012) find little relationship between religious commitment and ethical judgment when their respondents were divided on the basis of broad faith categories - Catholic, Protestant, Jewish, other religions, and no religion. Respondents who indicated that religious interests were of high or moderate importance to them demonstrated less accepting of unethical decisions. In short, we conjecture that managers' EM behavior is influenced by both personal traits and social norms of the local community (fig. 1), including religiosity.

\section{The relationship between religiosity and earnings management}

The studies investigating the impact of religion on EM are very scant. Dyreng, Mayew and Williams (2012) state that religion promotes honesty and risk aversion in a system of social values and norms. The study of Bartke and Schwarze (2008) provide evidence suggesting that Moslems are significantly more risk-averse than Protestants and another study (Barsky, Juster, Kimball, \& Shapiro, 1997) shows that Protestants are more risk-averse than Catholics. Overall it is difficult to argue that different religious affiliations play the same or very similar role as a factor limiting propensity to EM.

Religiosity and its impact on the CEO's decision-making process is usually ascribed to the broader concept of business ethics. Goldman and Bounds (2015) provide an in-depth analysis of the business ethics definition and concluded that it deals with the values and rules of behavior of society while pursuing the objectives of an organization. Furthermore, they note that organizations (corporations included) do not necessarily act as ethically as their stakeholders expect them. On the other hand, as Mousa (2018) points out, ethical leadership fosters both individual and organizational performance.

Religion in local communities affects corporate behavior and business ethics and for this reason should be treated as a potential determinant of EM (Du, Jian, Zeng \& Du, 2014). 
Additionally, Du, Jian, Lai, Du and Pei (2015) state that "managers may not be religious believers, but they may be affected by the religious norms in a geographic area"(p. 700). They selected a Chinese context, where a dominant religion is Buddhism and Taoism. The nature and philosophy of these religions deter EM, considering it as unethical. The results show a negative association between religion and $\mathrm{EM}$, proving that religion is a set of social norms that have the potential to mitigate EM, especially in the case of emerging markets, where corporate governance mechanisms are weaker.

McGuire, Omer and Sharp (2012) hypothesize that there is an influence of godliness on reduced acceptance of unethical business practices like EM. On the basis of the sample consisted of US companies they found that religiosity has a negative impact on AEM and positive on REM, concluding that managers in firms located in more pious areas prefer REM over AEM.

Callen, Morel and Richardson (2011) analyzed the link between EM and different culture dimensions and religiosity. The latter is considered to be an additional layer of culture. Based on other studies they noted that religiosity mitigates criminality and tax avoidance, and therefore for the same reasons it should limit EM. They note that religiosity is a very complex social construct and phenomenon. The consequence is the problem of its measurability. Finally, they decided to use measures proposed by Stack and Kposowa (2006). Therefore, they use as a proxy for religiosity: the degree of public participation in religious rituals and individual determination based on surveys. The results of the study show that the culture influences EM, but only in the dimension of individualism (negatively) and uncertainty avoidance (positively). They concluded there is no proof of the statistical influence of religiosity or religion denomination on EM.

\section{Religiosity vs. wealthiness around the world. The problem of proxy for religiosity}

Gallup surveys conducted in 114 countries in 2009 show that religion continues to play an important role in many people's lives worldwide. The global median proportion of adults who declared that religion is an important part of their daily lives was $84 \%$, unchanged from what Gallup has found in other years. There is a strong negative relationship between a country's socioeconomic status and the religiosity of its residents. In the world's poorest countries (average GDP per capita of $\$ 2,000$ or lower) the median proportion who say religion is important in their daily lives is $95 \%$. In contrast, the median for the richest countries (average GDP per-capita higher than $\$ 25,000$ ) is $47 \%$. The United States is one of the rich countries which is exception to the trend. About $65 \%$ of Americans declared that religion is important in their daily lives. Among high-income countries, only Italians, Greeks, Singaporeans, and residents of the Persian Gulf states are more likely to say that religion is important (Gallup, 2010).

Poland seems to be the next exception. The level the religiosity estimated according to Gallup's survey in Poland is the highest among countries classified by FTSE Russell (2019) as developed. Furthermore, Polish religiosity is unique because it is mainly Catholic: $87 \%$ of citizens declare themselves Catholics, while $78 \%$ in Italy, $77 \%$ in Portugal, $75 \%$ in Austria and Lithuania, and $72 \%$ in Ireland (PEW Research Center, 2018a). There are other mono-religion Orthodox countries in Europe - Moldova, Greece, Georgia, Armenia, Serbia, Romania - but their level of economic development is much lower. Therefore, Poland represents a unique opportunity from researchers' perspective - a mono- 
religious country with a relatively strong economy and capital market, which allows avoiding problems with religious differences.

PEW Research Center (2018b) surveyed the level of religiosity of respondents in 34 European countries in 2015-2017. The findings differ from the Gallup (2010) survey. The difference may result from the time span between surveys. PEW created the overall index by combining four individual measures of religious observance (1) self-assessment of religion's importance in one's life, (2) religious attendance, (3) frequency of prayer, and (4) belief in God. The results are presented in Table 1. All European FTSE (2019) developed countries are marked as bold. According to the overall PEW index, Poland is still the most religious developed European country. Similar conclusion can be drawn comparing individually percentage of respondents who declare that religion is very important in their lives (rank 10 in column "Ranking (1)"), who declare that they pray daily (rank 11 in column "Ranking (3)"), and those who declare that they believe in God with absolute certainty (rank 9 in column "Ranking (4)"). The surprising finding is that Poles are absolutely the most religious people in Europe considering the percentage of respondents who declare worship services attendance at least monthly (rank 1 in column "Ranking (2)").

The above conclusion brings a challenge for earnings management and religiosity-related empirical research. Findings may depend heavily on the choice of proxy for religiosity. A researcher must consider the following issue: is observed or declared religiosity in a country, e.g. Poland, a matter of tradition and culture, or it is a signal of personal faith? The former may not influence managers' real action and EM behavior, the latter may have a significant impact on the level of EM and finally earnings quality.

\section{CONCLUSIONS}

The above literature review shows that despite a significant number of papers on earnings quality, earnings management, and ethical issues in this area there are still avenues for future research. The impact of religiosity may be especially interesting, nevertheless a researcher faces several problems.

First major implication of the study is demonstrating the lack of universal measure of earnings quality. The described measures refer to various aspects of the broad notion of the EQ. From a decision-usefulness perspective, it seems that one should focus on discretionary accruals, but the research findings do not show without any ambiguity the superiority of any model for these accruals.

Secondly, many models for abnormal accruals estimation assume implicitly that managerial intervention in the reporting process occurs via accounting practices - accrual earnings management (AEM), but managers may also manage earnings through operational decisions - real earnings management (REM). It implies the possible trade-off between AEM and REM should be considered.

Thirdly, the proxy for religiosity is complex issue of. The quoted above surveys provide data on the level of religiosity in a given country. In the case of firm-level research one needs data on religiosity in a given area or firm, the most desirable data describe personal religiosity of firms' top executives. Next, which proxy to choose? A case of Poland (and also Italy, see Table 1) shows that reasonable proxies may differ greatly. The problem of multi-religion countries arises too. How to proxy religious commitment in a country like Israel, with three broad religion categories, or in Poland, single-religion Catholic country, and 
Table 1. Level of religiosity across European countries

\begin{tabular}{|c|c|c|c|c|c|c|c|c|c|c|}
\hline Country & $\begin{array}{l}\text { Overall } \\
\text { index }\end{array}$ & Rank & (1) & $\begin{array}{c}\text { Rank } \\
\text { (1) }\end{array}$ & (2) & $\begin{array}{l}\text { Rank } \\
\text { (2) }\end{array}$ & (3) & $\begin{array}{l}\text { Rank } \\
\text { (3) }\end{array}$ & (4) & $\begin{array}{c}\text { Rank } \\
\text { (4) }\end{array}$ \\
\hline Romania & $55 \%$ & 1 & $50 \%$ & 4 & $50 \%$ & 2 & $44 \%$ & 3 & $64 \%$ & 4 \\
\hline Armenia & $51 \%$ & 2 & $53 \%$ & 3 & $34 \%$ & 12 & $45 \%$ & 2 & $79 \%$ & 1 \\
\hline Georgia & $50 \%$ & 3 & $50 \%$ & 4 & $39 \%$ & 5 & $38 \%$ & 5 & $73 \%$ & 2 \\
\hline Greece & $49 \%$ & 4 & $55 \%$ & 1 & $38 \%$ & 6 & $29 \%$ & 9 & $59 \%$ & 5 \\
\hline Moldova & $47 \%$ & 5 & $42 \%$ & 6 & $35 \%$ & 9 & $48 \%$ & 1 & $55 \%$ & 8 \\
\hline Bosnia & $46 \%$ & 6 & $54 \%$ & 2 & $35 \%$ & 9 & $32 \%$ & 7 & $66 \%$ & 3 \\
\hline Croatia & $44 \%$ & 7 & $42 \%$ & 6 & $40 \%$ & 4 & $40 \%$ & 4 & $57 \%$ & 7 \\
\hline Poland & $40 \%$ & 8 & $29 \%$ & 10 & $61 \%$ & 1 & $27 \%$ & 11 & $45 \%$ & 9 \\
\hline Portugal & $37 \%$ & 9 & $36 \%$ & 8 & $36 \%$ & 8 & $37 \%$ & 6 & $44 \%$ & 10 \\
\hline Serbia & $32 \%$ & 10 & $34 \%$ & 9 & $19 \%$ & 22 & $27 \%$ & 11 & $58 \%$ & 6 \\
\hline Ukraine & $31 \%$ & 11 & $22 \%$ & 13 & $35 \%$ & 9 & $29 \%$ & 9 & $32 \%$ & 13 \\
\hline Slovakia & $29 \%$ & 12 & $23 \%$ & 11 & $31 \%$ & 13 & $31 \%$ & 8 & $37 \%$ & 11 \\
\hline Belarus & $27 \%$ & 13 & $20 \%$ & 16 & $30 \%$ & 14 & $25 \%$ & 13 & $26 \%$ & 16 \\
\hline Italy & $27 \%$ & 13 & $21 \%$ & 15 & $43 \%$ & 3 & $21 \%$ & 15 & $26 \%$ & 16 \\
\hline Ireland & $24 \%$ & 15 & $23 \%$ & 11 & $37 \%$ & 7 & $19 \%$ & 17 & $24 \%$ & 21 \\
\hline Lithuania & $21 \%$ & 16 & $16 \%$ & 20 & $27 \%$ & 17 & $15 \%$ & 23 & $34 \%$ & 12 \\
\hline Spain & $21 \%$ & 16 & $22 \%$ & 13 & $23 \%$ & 19 & $23 \%$ & 14 & $25 \%$ & 19 \\
\hline Bulgaria & $18 \%$ & 18 & $19 \%$ & 18 & $19 \%$ & 22 & $15 \%$ & 23 & $30 \%$ & 14 \\
\hline Netherlands & $18 \%$ & 18 & $20 \%$ & 16 & $18 \%$ & 24 & $20 \%$ & 16 & $15 \%$ & 24 \\
\hline Hungary & $17 \%$ & 20 & $14 \%$ & 22 & $17 \%$ & 25 & $16 \%$ & 22 & $26 \%$ & 16 \\
\hline Norway & $17 \%$ & 20 & $19 \%$ & 18 & $16 \%$ & 27 & $18 \%$ & 18 & $19 \%$ & 23 \\
\hline Russia & $17 \%$ & 20 & $15 \%$ & 21 & $17 \%$ & 25 & $17 \%$ & 20 & $25 \%$ & 19 \\
\hline Latvia & $15 \%$ & 23 & $10 \%$ & 27 & $16 \%$ & 27 & $17 \%$ & 20 & $28 \%$ & 15 \\
\hline Austria & $14 \%$ & 24 & $12 \%$ & 23 & $30 \%$ & 14 & $8 \%$ & 32 & $13 \%$ & 27 \\
\hline Finland & $13 \%$ & 25 & $10 \%$ & 27 & $10 \%$ & 33 & $18 \%$ & 18 & $23 \%$ & 22 \\
\hline France & $12 \%$ & 26 & $11 \%$ & 24 & $22 \%$ & 20 & $11 \%$ & 25 & $11 \%$ & 32 \\
\hline Germany & $12 \%$ & 26 & $11 \%$ & 24 & $24 \%$ & 18 & $9 \%$ & 29 & $10 \%$ & 34 \\
\hline Switzerland & $12 \%$ & 26 & $9 \%$ & 31 & $29 \%$ & 16 & $8 \%$ & 32 & $11 \%$ & 32 \\
\hline United Kingdom & $11 \%$ & 29 & $10 \%$ & 27 & $20 \%$ & 21 & $6 \%$ & 34 & $12 \%$ & 31 \\
\hline Belgium & $10 \%$ & 30 & $11 \%$ & 24 & $11 \%$ & 30 & $11 \%$ & 25 & $13 \%$ & 27 \\
\hline Sweden & $10 \%$ & 30 & $10 \%$ & 27 & $11 \%$ & 30 & $11 \%$ & 25 & $14 \%$ & 26 \\
\hline Czech Republic & $8 \%$ & 32 & $7 \%$ & 33 & $11 \%$ & 30 & $9 \%$ & 29 & $13 \%$ & 27 \\
\hline Denmark & $8 \%$ & 32 & $8 \%$ & 32 & $12 \%$ & 29 & $10 \%$ & 28 & $15 \%$ & 24 \\
\hline Estonia & $7 \%$ & 34 & $6 \%$ & 34 & $10 \%$ & 33 & $9 \%$ & 29 & $13 \%$ & 27 \\
\hline
\end{tabular}

Interpretation of columns' tiles: $1-\%$ who say religion is very important in their lives; $2-\%$ who say they attend worship services at least monthly; $3-\%$ who say they pray daily; $4-\%$ who say they believe in God with absolute certainty.

Source: authors' own elaboration on the basis of (PEW Research Center, 2018b).

Romania, single-religion Orthodox one? The possible answer to the last question is a survey, but in such a case one collects data on declarations, not real action. Finally he or she will not know whether the declarations reflect personal beliefs, influence of the group, or both. 
Our study has also some limitations. We limited our review to top-rated English-language journals. It is possible that there are unmentioned important papers or monographs published in the national languages.

We identify some avenues for further research. First, mostly normative research may concentrate on clear definition and measure of eanings quality. Second, the relationship between earnings quality and earnings management need to be developed. Third, the reasoning behind the choice of proxy for religiosity needs to be devloped with respect to psychological and sociological theories.

\section{REFERENCES}

Arya, A., Glover, J., \& Sunder, S. (2003). Are Unmanaged Earnings Always Better for Shareholders?. Accounting Horizons, 17, 111-116. https://doi.org/10.2308/acch.2003.17

Ball, R., \& Brown, P. (1968). An Empirical Evaluation of Accounting Income Numbers. Journal of Accounting Research, 6(2), 159-178. https://doi.org/10.2307/2490232

Barsky, R.B., Juster, F.T., Kimball, M.S., \& Shapiro, M.D. (1997). Preference parameters and behavioral heterogeneity: An experimental approach in health and retirement study. Quarterly Journal of Economics, 112(2), 537-579. https://doi.org/10.1162/003355397555280

Bartke, S., \& Schwarze, R. (2008). Risk-averse by Nation or by Religion? Some Insights on the Determinants of Individual Risk Attitudes. SOEP paper on Multidisciplinary Panel Data Research, 131, Deutsches Institut fur Wirtschaftsforschung. http://dx.doi.org/10.2139/ssrn.1285520

Beaver, W. (1968). The Information Content of Annual Earnings Announcements. Journal of Accounting Research, Supplement 6, 67-92. https://doi.org/10.1007/s11142-017-9417-z

Beneish, M. (2001). Earnings management: a perspective. Managerial Finance, 27(12), 3-17. https://doi.org/10.1108/03074350110767411.

Callen, J.L., Morel, M., \& Richardson, G. (2011). Do culture and religion mitigate earnings management? Evidence from a cross-country analysis. International Journal of Disclosure and Governance, 8(2), 103-121. https://doi.org/10.1057/jdg.2010.31

Conroy, S.J., \& Emerson, T.L.N. (2004). Business ethics and religion: Religiosity as a predictor of ethical awareness among students. Journal of Business Ethics, 50(4), 383-396. https://doi.org/10.1023/B:BUSI.0000025040.41263.09

Daly, A. (2018). The incremental informativeness of public subsidiary earnings. International Journal of Accounting \& Information Management, 26(2), 272-290. https://doi.org/10.1108/IJAIM-01-2017-0007.

Dechow, P., \& Dichev, I. (2002). The quality of accruals and earnings: The role of accrual estimation errors. The Accounting Review, 77(Supplement), 35-59. https://doi.org/10.2308/accr.2002.77

Dechow, P., Ge, W., \& Schrand, C. (2010). Understanding earnings quality: A review of the proxies, their determinants and their consequences. Journal of Accounting and Economics, 50(2/3), 344401. https://doi.org/10.1016/j.jacceco.2010.09.001

Dechow, P.M., Kothari, S.P., \& Watts, R.L. (1998). The relation between earnings and cash flows. Journal of Accounting and Economics, 25(2), 133-168. https://doi.org/10.1016/S01654101(98)00020-2

Dechow, P.M., Sloan, R.G., \& Sweeney, A.P. (1995). Detecting Earnings Management. The Accounting Review, 70(2), 193-225.

Du, X., Jian, W., Lai S., Du, Y., \& Pei, H. (2015). Does Religion Mitigate Earnings Management? Evidence from China. Journal of Business Ethics, 131(3), 699-749. https://doi.org/10.1007/s10551-014-2290-9 
Du, X., Jian, W., Zeng, Q., \& Du, Y. (2014). Corporate Environmental Responsibility in Polluting Industries: Does Religion Matter?. Journal of Business Ethics, 124(3), 485-507. https://doi.org/10.1007/s10551-013-1888-7

Dyreng, S.D., Mayew, W.J., \& Williams, Ch.D. (2012). Religious Social Norms and Corporate Financial Reporting. Journal of Business Finance \& Accounting, 39(7\&8), 845-875. https://doi.org/10.1111/j.1468-5957.2012.02295.x

Eliwa, Y., Gregoriou, A., \& Paterson, A. (2019). Accruals quality and the cost of debt: the European evidence. International Journal of Accounting \& Information Management, 27(2), 333-351. https://doi.org/10.1108/IJAIM-01-2018-0008.

Ewert, R., \& Wagenhofer, A. (2012). Earnings Management, Conservatism, and Earnings Quality. Foundations and Trends in Accounting, 6(2), 65-186. http://dx.doi.org/10.1561/1400000025

FASB. (2010). Statement of Financial Accounting Concepts No. 8. Retrived on November 3, 2019 from https://www.fasb.org/resources/ccurl/515/412/Concepts\%20Statement\%20No\%208.

Francis, J., LaFond, R., Olsson, P., \& Schipper, K. (2004). Costs of equity and earnings attributes. The Accounting Review, 79(4), 967-1010. https://doi.org/10.2308/accr.2004.79.4.967

Francis, J., Olsson, P., \& Schipper, K. (2006). Earnings Quality. Foundations and Trends in Accounting, 1(4), 259-340. http://dx.doi.org/10.1561/1400000004

FTSE Russell. (2019). FTSE Equity Country Classification Process. Retrieved on November 4, 2019 from https://research.ftserussell.com/products/downloads/FTSE_Equity_Country_Classification_Paper.pdf?_ga=2.267896846.1440652547.1574338853-2120429378.1574338853

Gallup. (2010). Religiosity Highest in World's Poorest Nations. The United States is among the rich countries that buck the trend. Retrieved on November 5, 2019 from https://news.gallup.com/poll/142727/religiosity-highest-world-poorest-nations.aspx

Goldman, G., \& Bounds, M. (2015). Ethical Conduct in Business Organisations: The Opinion of Management Students in Gauteng. Entrepreneurial Business and Economics Review, 1(3), 9-27. https://doi.org/10.15678/EBER.2015.030102

Grabiński, K. (2016). Determinanty aktywnego kształtowania wyniku finansowego w teorii i praktyce europejskich spółek giełdowych. Kraków: Uniwersytet Ekonomiczny w Krakowie.

Grabiński, K., Kędzior M., \& Krasodomska J. (2014). Współczesna rachunkowość na rynkach kapitałowych. Warszawa: Difin.

Graham, B., \& Dodd, D. (1934). Security Analysis. New York: The McGraw-Hill Book Company Inc.

Gremion, C., Boyko, K.E., \& Boddewyn, J. (1972). Toward a new theory of decision-making. International Studies of Management \& Organization, 2(2), 125-141.

Hambrick, D.C. (2007). Upper Echelons Theory: An Update. Academy of Management Review, 32(2), 334-343. https://doi.org/10.5465/amr.2007.24345254

Hambrick, D.C., \& Finkelstein, S. (1987). Managerial discretion: A bridge between polar views of organizational outcomes. Research in Organizational Behavior, 9, 369-406.

Hambrick, D.C., \& Mason, P.A. (1984). Upper Echelons: The Organization as a Reflection of Its Top Managers. Academy of Management Review, 9(2), 193-206. https://doi.org/10.5465/amr.1984.4277628

Healy, P.M., \& Wahlen, J.M. (1999). A Review of the Earnings Management Literature and Its Implications for Standard Setting. Accounting Horizons, 13(4), 365-383. https://doi.org/10.2308/acch.1999.13.4.365

Hicks, J. R. (1946). Value and Capital. Oxford: Clarendon.

Jakubowski, S.T., \& Wójtowicz, P. (2019). The incremental informativeness of sell-side earnings forecasts. Evidence for Warsaw Stock Exchange. Zeszyty Teoretyczne Rachunkowości, 105(161), in press. 
Jones, J. (1991). Earnings management during import relief investigations. Journal of Accounting Research, 29(2), 193-228. https://doi.org/10.2307/2491047

Karamanou, I. (2012). Value relevance of analyst earnings forecasts in emerging markets. Advances in Accounting, incorporating Advances in International Accounting, 28(1), 128-137. https://doi.org/10.1016/j.adiac.2012.03.002

Kohlberg, L. (1984). The Psychology of Moral Development: Essays on Moral Development. San Francisco: Harper \& Row.

Lev, B. (1989). On the Usefulness of Earnings and Earnings Research: Lessons and Directions from Two Decades of Empirical Research. Journal of Accounting Research, 27 (Supplement), 153-192. https://doi.org/10.2307/2491070

Longenecker, J.G., McKinney, J.A., \& Moore, C.W. (2004). Religious intensity, evangelical Christianity, and business ethics: An empirical study. Journal of Business Ethics, 55(4), 373-386. https://doi.org/10.1007/s10551-004-0990-2

McGuire, S.T., Omer, T.C., \& Sharp, N.Y. (2012). The Impact of Religion on Financial Reporting Irregularities. The Accounting Review, 87(2), 645-673. https://doi.org/10.2308/accr-10206

Mousa, M. (2018). Inspiring Work-Life Balance: Responsible Leadership among Female Pharmacists in the Egyptian Health Sector. Entrepreneurial Business and Economics Review, 1(6), 71-90. https://doi.org/10.15678/EBER.2018.060104

Nanda, F., Leuz, C. \& Wysocki, P.D. (2003). Earnings Management and Investor Protection: An International Comparison. Journal of Financial Economics, 69(3), 505-527. https://doi.org/10.1016/S0304-405X(03)00121-1

Nelson M.W., \& Skinner D.J. (2013). How should we think about earnings quality? A discussion of "Earnings quality: Evidence from the field". Journal of Accounting and Economics, 56(Supplement), 34-41. https://doi.org/10.1016/j.jacceco.2013.10.003

Perotti, P., \& Wagenhofer, A. (2014). Earnings Quality Measures and Excess Returns. Journal of Business, Finance \& Accounting, 41(5-6), 545-571. https://doi.org/10.1111/jbfa.12071PEW Research Center. (2018a). Eastern and Western Europeans Differ on Importance of Religion, Views of Minorities, and Key Social Issues. Retrieved on November 5, 2019 from http://www.pewforum.org/2018/10/29/eastern-and-western-europeans-differ-on-importance-of-religion-viewsof-minorities-and-key-social-issues/

PEW Research Center. (2018b). How religious is your country?. Retrieved on November 6, 2019 from https://www.pewresearch.org/interactives/how-religious-is-your-country/

Ronen, J., \& Yaari, V. (2008). Earnings Management. Emerging Insights in Theory, Practice and Research. New York: Springer.

Roychowdhury, S. (2006). Earnings management through real activities manipulation. Journal of Accounting and Economics, 42(3), 335-370. https://doi.org/10.1016/j.jacceco.2006.01.002

Schipper, K. (1989). Commentary on Earnings Management. Accounting Horizons, 3(4), 91-102.

Schipper, K., \& Vincent, L. (2003). Earnings Quality. Accounting Horizons, 17(Supplement), 97-110. https://doi.org/10.2308/acch.2003.17.s-1.97

Stack, S., \& Kposowa, A. (2006). The effect of religiosity on tax fraud acceptability: A cross-national analysis. Journal for the Scientific Study of Religion, 45(3), 325351.https://doi.org/10.1111/j.1468-5906.2006.00310.x

Stubben, S.R. (2010). Discretionary Revenues as a Measure of Earnings Management. The Accounting Review, 85(2), 695-717. https://doi.org/10.2308/accr.2010.85.2.695 


\section{Authors}

Contribution share of authors is equal and amounted to $50 \%$ each of them.

\section{Konrad Grabiński}

Master of finance and banking (Cracow Academy of Economics), PhD dissertation in 2009 (Cracow University of Economics) and habilitation in 2017 (Cracow University of Economics). His research interests include earnings management, capital market research in accounting, earnings quality, financial reporting and corporate finance.

Correspondence to: Prof. UEK, dr hab. Konrad Grabiński, Department of Financial Accounting, College of Economics, Finance and Law, Cracow University of Economics, Rakowicka st. 27, 31-510 Cracow, e-mail: kg@uek.krakow.pl

ORCID (1) http://orcid.org/0000-0002-1071-3317

\section{Piotr Wójtowicz}

Master of economics (Cracow Academy of Economics), PhD dissertation in 2000 (Cracow University of Economics) and habilitation in 2011 (Cracow University of Economics). His research interests include earnings management, earnings quality, financial reporting, business ethics.

Correspondence to: Prof. UEK, dr hab. Piotr Wójtowicz, Department of Accounting, College of Management Sciences and Quality, Cracow University of Economics, Rakowicka st. 27, 31-510 Cracow, e-mail: piotr.wojtowicz@uek.krakow.pl

ORCID (1) http://orcid.org/0000-0001-5054-9964

\section{Acknowledgements and Financial Disclosure}

The publication was co-financed from the subsidy granted to the Cracow University of Economics. The authors would like to thank the anonymous referees for their useful comments, which allowed to increase the value of this article.

\section{Copyright and License}

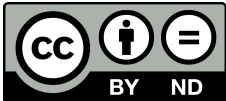

This article is published under the terms of the Creative Commons

Attribution - NoDerivs (CC BY-ND 4.0) License

http://creativecommons.org/licenses/by-nd/4.0/

\section{Published by the Centre for Strategic and International Entrepreneurship - Krakow, Poland}


